ks. Marek Jagodzinski

Katolicki Uniwersytet Lubelski

\title{
Komunijny wymiar integralności człowieka
}

\section{COMMUNIAL DIMENSION OF INTEGRITY OF MAN}

Personal integration of man is expressed in the unity of his body and soul. The body is "great-symbol" of spirituality and the spiritual nature is the basis of interpersonal communication and communion. Anthropological bipolarity (spirit - body, male - female, single individual - community) creates communional tension, in which communional importance has body and soul of man. Communional integrity of man is revealed most fully in christological context - in the hypostatic union and resurrection of Jesus Christ.

Key words: spirit, integrity, communicatio, communion, hypostatic union, resurrection.

Podstawowym faktem antropologicznym, wynikającym z pierwotnej struktury człowieka jest nieprzezwyciężalna - podwójna jedność duszy i ciała. Człowiek nie ma duszy i ciała, lecz jest duszą i ciałem ${ }^{1}$. Teologiczna analiza biblijnego opisu stworzenia ukazuje, że Bóg stworzył człowieka jako jedność, a jego dusza i ciało są tak samo przeciwnymi biegunami, jak i komplementarnymi elementami, w których objawia się integralność ludzkiej osoby². Wewnątrz tej integralności natura cielesna człowieka jest przekraczana przez duszę, ale dusza jest nakierowana w swej abstrakcyjności na cielesność będącą nośnikiem jej urzeczywistnienia w osobie. Ciało jest symbolem duszy, która ujawnia się w ciele, a jedność ciała i duszy w człowieku nie oznacza kwantytatywnej sumy części - każda z nich (ciało i dusza) zawiera w sobie

Por. A Scola, Osoba ludzka. Antropologia teologiczna, Poznań 2005, s. 178.

2 Por. tamże, 158-181. Zob. C. S. Bartnik, Dogmatyka katolicka, t. I, s. 389-398. 
całość, jakkolwiek w różnej mierze ${ }^{3}$. Ponieważ ciało jest pierwotnym nagromadzeniem świata, odnoszącym się w duchowości do człowieka i stanowiącym podstawę osoby - można je traktować jako „prasymbol” duchowości ${ }^{4}$. Duchowa natura człowieka jest ponadto plastyczną podstawą możliwości bycia sobą i bycia z innymi ${ }^{5}$ - komunikacji i komunii, a wyrażanie samego siebie w materii i w dialogu międzyosobowym jest dla człowieka istotowo konstytutywnym czynnikiem osobowego ducha i wolności ${ }^{6}$. Właśnie potrzeba i wyrażanie siebie w komunikacyjnym dialogu międzyludzkim - angażującym duszę i ciało uczestniczących w nim osób - jest najwyraźniejszym faktorem komunijnej integralności człowieka.

\section{Komunijne napięcie w człowieku}

Biblijny przekaz Księgi Rodzaju potwierdza, że w strukturę człowieka wpisana jest pewna diadyczność, dwubiegunowość będąca szczególnym wyrazem i najpełniejszym urzeczywistnieniem dialogiczności. Można powiedzieć, że ludzką strukturę osobową charakteryzuje nieustanne napięcie między tożsamością a różnicą, które przejawia się w konstytutywnych biegunowościach antropologicznych: duch - ciało, mężczyzna - kobieta, jednostka - wspólnota ${ }^{7}$. Podstawowy egzystencjał osoby ludzkiej stanowi to napięcie, będące postawą i elementem ciągle

3 Por. H. O. Meuffels, Kommunikative Sakramententheologie, Freiburg - Basel - Wien 1995, 77; M. Jagodziński, Antropologiczno-komunikacyjne podstawy sakramentów, „Studia Diecezji Radomskiej” t. VI, Radom 2004, 247-250; G. Haeffner, Wprowadzenie do antropologii filozoficznej, tłum. W. Szymona, Kraków 2006, s. 178-192.

Por. H. Wagner, Dogmatyka, tłum. J. Zychowicz, Kraków 2007, s. 258.

5 Por. A. Ganoczy, Einführung in die katholische Sakramentenlehre, Darmstadt 1979, s. 110n.

6 Por. G. L. Müller, Katholische Dogmatik. Für Studium und Praxis der Theologie, Freiburg - Basel - Wien ${ }^{3} 1995$, s. 652; M. Jagodziński, Sakramenty w stużbie communio. Studium teologiczno-komunikacyjne, s. 172n; S. Kunka, Teologiczna wizja cielesności człowieka w nauczaniu Karola Wojtyty - Jana Pawła II, Lublin 2012, s. 80-88.

7 Na taką dwubiegunowość wskazuje także H. U. von Balthasar, Teodramatyka, t. II: Osoby dramatu, cz. I: Człowiek w Bogu, Kraków 2006, s. 178-322. Powołuje się w tym na Ericha Przywarę, Deus semper maior. Theologie der Exerzitien, t. 1, Wien 1964, s. 49-68. Por. A. Scola, Osoba ludzka..., dz. cyt., s. 157n; A. Perzyński, Włoska antropologia teologiczna. Studium historyczno-dogmatyczne, Łódź2012, s. 185n; J. Kupczak, Teologiczna semantyka ptci, Kraków 2013, s. 142n. 
urzeczywistniającym się w relacji. Człowiek uświadamia sobie, że musi nieustannie szukać swojego dopełnienia w przeciwstawnym biegunie ${ }^{8}$.

Nie może on zrozumieć żadnego z powyższych wymiarów i aspektów tajemnicy swojego człowieczeństwa, które jest współczłowieczeństwem, jeśli nie odwoła się do tego „drugiego”, w którym znajduje swoje własne wyjaśnienie oraz integrację. Chociaż wszystkie te biegunowości nie sytuują się na tym samym poziomie, to jednak w nich wszystkich człowiek: jako ciało i dusza, jako mężczyzna i kobieta, jako pojedyncza czy wspólnotowa osoba jest „wizerunkiem Boga”, będąc stworzonym na Jego „obraz i podobieństwo” (Rdz 1, 26). Dopiero owa komplementarność, mająca w Bogu swoje źródło i właściwe znaczenie, ukazuje człowieka jako „obraz”, niosący myśl o swoim „Pierwowzorze”, w którym istnieje wzajemne odniesienie, relacja, słowo, komunikacja. Owa biegunowa struktura, można by rzec: „dwoista-jedność” czy też „jedność przeciwieństw”, jaką jest człowiek, w tej właśnie perspektywie [...] odkrywa swój najgłębszy sens oraz znajduje właściwą sobie stałość. Najważniejszym, bo odzwierciedlającym każde inne odniesienie do tego „drugiego bieguna”, jest odniesienie do Boga, z którego wyłania się nowość nieskończonego horyzontu widzenia każdej innej relacji, w jakiej znajduje się - czy to z konieczności, czy w sposób wolny - człowiek ${ }^{9}$.

8 Por. G. Barth, Hermeneutyka osoby, Lublin 2013, s. 137-139.

Tamże, s. 139n. „«Słowo» Boga jest nie tylko słowem stwarzającym oraz inicjującym wszelki możliwy dialog z człowiekiem, ale raz wypowiedziane będzie już zawsze słowem odpowiedzi na wszelki brak odkryty przez człowieka; będzie słowem zaskakująco przerastającym horyzont, w którym dokonywało się poprzednie dochodzenie do prawdy o sobie. Najpierw tym «słowem» była kobieta przerastająca porządek świata istot stworzonych, który Adam wcześniej określił i uporządkował, a następnie «Słowem» tym stał się Logos, który w sposób przewyższający wszelkie możliwe próby ludzkiego pojmowania określił i uporządkował wszystko, a przede wszystkim na nowo zdefiniował człowieka. Od tej chwili, niezależnie od tego, czy człowiek będzie pojmował siebie jako dwoistą-jedność ducha i ciała, mężczyzny i kobiety jednostki i wspólnoty, to zawsze obraz ten będzie musiał być oświetlony światłem Logosu pochodzącego od Boga. Właśnie dzięki temu jednemu odniesieniu człowiek może w każdej innej relacji, która w sobie właściwy sposób odsłoni jego cechy osobowe, zobaczyć je w prawdzie i pełnym bogactwie" (tamże, s. 140). 


\section{Komunijne znaczenie ciała człowieka}

Ciało człowieka ${ }^{10}$ jest „realnym symbolem”"11 (K. Rahner) lub „znakiem realizującym" (P. Schoonenberg). Jest ono najsilniejszym znakiem realizującym osobową bliskość człowieka, wskazującym i wyrażającym konkretną ludzką osobę, nieidentyfikującym się jednak z nią w prosty sposób ${ }^{12}$. W nim urzeczywistnia się osoba konkretnego człowieka jego ,ja”, zachowania, myślenie i działania, realizacja siebie ${ }^{13}$ (jest to „dynamiczne bycie ciałem"14). Ciało człowieka ma więc także charakter duchowy, gdyż jest wyrazem ducha ${ }^{15}$.

Lansowany dzisiaj nachalnie feminizm egalitarny głosi, że należy ignorować różnice biologiczne i psychiczne męskiego i kobiecego ciała człowieka w celu osiągnięcia osobowej tożsamości będącej w ostateczności wyrazem wolnego wyboru i decyzji jednostki. Feminizm różnicy traktuje jednak poważnie te odmienności płciowe, zakorzenione w psychosomatycznej strukturze ciała mężczyzny i kobiety ${ }^{16}$. Podstawowe cechy chrześcijańskiej teorii tożsamości płciowej człowieka można scharakteryzować następująco:

Primo, podstawową zasadą mówienia o różnicy płciowej między mężczyzną i kobietą jest ich równość w osobowej godności, która płynie z samego faktu stworzenia człowieka „mężczyzną i niewiastą” (Rdz 1,27), jak również z tego, że do każdego człowieka jest skierowany dar odkupienia w Chrystusie. Secundo, chrześcijańska antropologia stoi na stanowisku esencjalizmu płciowego, czyli przekonania, że istnieje realna różnica między mężczyzną i kobietą, którą możemy starać się opisać, filozoficznie i teologicznie. Tertio, tożsamość płciowa mężczyzny i kobiety zakorzeniona jest $\mathrm{w}$ psychosomatycznych różnicach w budowie ciała, męskiego i kobiecego [...] Quarto, w tworzeniu tożsamości mężczyzny i kobiety kluczowa jest zasada komplementarności płci,

Na temat terminologii i znaczenia „ciała” w Biblii zob. C. S. Bartnik, Dogmatyka..., dz. cyt., s. 374n.

G. L. Müller nazywa ciało realnym symbolem duszy (Katholische Dogmatik. Für Studium und Praxis der Theologie, Freiburg - Basel - Wien ${ }^{3} 1995$, s. 652). Por.

D. Emeis, Sakramentenkatechese, Freiburg - Basel - Wien 1991, s. 26.

Por. A. Skowronek, Sakramenty wogólności. Chrzest. Bierzmowanie, Włocławek 1995, s. 23.

13 Por. H. Wagner, Dogmatyka..., dz. cyt., s. 258.

14 Por. G. Haeffner, Wprowadzenie do antropologii..., dz. cyt., s. 120-122.

15 Por. J. Kupczak, Teologiczna semantyka..., dz. cyt., s. 45.

Por. tamże, s. 18-37. 
czyli przekonanie o wzajemnym uzupełnianiu się i ubogacaniu tego, co męskie i tego, co żeńskie ${ }^{17}$.

Warto przy tym podkreślić, że już w swojej biologicznej strukturze ciało mężczyzny i kobiety stworzone jest i służy do miłości ${ }^{18}$.

Cielesność człowieka jest w pewnym znaczeniu sakramentem, czyli widzialnym znakiem procesów duchowych, niedostępnych poza tym na drodze zmysłowej ${ }^{19}$. Nowsze badania egzegetyczne uwydatniły bardzo mocno taką właśnie wymowę całościowej antropologii hebrajskiej, która przetrwała także w Nowym Testamencie: język hebrajski nie zawiera słów będących odpowiednikami naszych pojęć „,ciała” i „duszy” jako elementów człowieka. Semickie basar i nefesz nie określają istniejących obok siebie części człowieka, lecz człowieka pod kątem ściśle określonego aspektu - pokrewieństwa i ułomności lub podarowanej przez Boga żywotności ${ }^{20}$. Chodzi tu więc o jedność ciała i duszy w człowieku. Biblijny obraz człowieka, ukazujący go - uczynionego z ziemi - jako jedność ziemi i oddechu życia, był przesłonięty przez długie wieki przez myśl grecką i zniekształcony jej dualizmem: ciało i dusza wydawały się być samodzielnymi, rozdzielonymi bytami, które tylko połowicznie jednoczyły się w człowieku. Święty Tomasz z Akwinu odzyskał pierwotną wizję jedności: w człowieku istnieje tylko jedna zasada rzeczywistości (forma - dusza), która urzeczywistnia się w możnościowej zasadzie (materii), konstytuując jednego i całego człowieka ${ }^{21}$.

Samotność człowieka w opisie jahwistycznym była nie tylko pierwszym odkryciem właściwej dla osoby transcendencji, lecz także

Tamże, s. 38. Por. C. Anderson, J. Granados, Wprowadzenie do teologii ciała Jana Pawta II, Warszawa 2011, s. 25-103.

Por. J. Kupczak, Teologiczna semantyka..., dz. cyt., s. 48n. Warto tu wskazać na audiobook z tekstami ks. Marka Dziewieckiego, zatytułowany Ciało. Narzędzie do kochania („Pure Profit” 2014). Na okładce autor umieścił następujące słowa: „Czy zastanawiałeś się nad tym, jakie są Twoje «ustawienia fabryczne»? Bóg zaprojektował Cię jak istotę doskonałą. [...] Istniejemy w świecie w sposób widzialny za pomocą ciała. [...] człowiek odkrywa, że ciało przynależy do niego, ale on sam nie mieści się we własnej cielesności. Jest czymś więcej. Można wyjść ponad to, czego chce tylko moje ciało np. w imię miłości”.

Por. A. Skowronek, Sakramenty..., dz. cyt., s. 25n.

Por. T. Schneider, Znaki bliskości Boga. Zarys sakramentologii, Wrocław 1990, s. 16-17; A. Perzyński, Włoska antropologia..., dz. cyt., s. 39, 46; A. Scola, Osoba ludzka..., dz. cyt., s. 161n. Język nowotestamentowy sięga Starego Testamentu, jakkolwiek przejście do języka greckiego powoduje obecność w nim pewnych odgłosów myśli hellenistycznej (por. tamże, s. 162-164).

21 Por. T. Schneider, Znaki bliskości..., dz. cyt., s. 17n; A. Scola, Osoba ludzka..., dz. cyt., s. 175; M. Jagodziński, Sakramenty w stużbie communio..., dz. cyt., s. 173n. 
otwarciem i oczekiwaniem na komunię osób ${ }^{22}$. Ciało wyraża kobiecość dla męskości i męskość dla kobiecości oraz ułatwia wzajemność i komunię osób ${ }^{23}$, a komunia małżeńska zakorzeniona jest w naturalnych więzach ciała i $\mathrm{krwi}^{24}$. Ciało samo w sobie nie jest wyrazem Bożego podobieństwa i obrazu - Bóg nie ma ciała. Ponieważ jednak ciało należy do natury człowieka i bierze udział w realizowaniu się osoby ludzkiej dzięki komunii z innymi osobami, uczestniczy w tym obrazie i podobieństwie. Perspektywa trynitarna, zakładająca przedmiotowy (,strukturalny”) status obrazu Bożego w człowieku, implikuje jego status komunijny (,relacyjny”) ${ }^{25}$.

\section{Problem z cielesnym zmartwychwstaniem człowieka}

Specyficzny problem cielesności stanowi chrześcijańskie nauczanie o wskrzeszeniu wszystkich umarłych w Chrystusie (por. 1 Kor 15, 20). Już Koryntianie pytali Pawła, w jaki sposób wskrzeszani są umarli i w jakim ciele przychodzą? (1 Kor 15, 35). Apostoł odpowiadał: „Zasiewa się zniszczalne - powstaje zaś niezniszczalne; sieje się niechwalebne - powstaje chwalebne; sieje się słabe - powstaje mocne; zasiewa się ciało zmysłowe - powstaje ciało duchowe. Jeżeli jest ciało ziemskie powstanie też ciało niebieskie" (1 Kor 15, 42-44). Wacław Hryniewicz komentuje tę wypowiedź ideą upodobnienia mocy zmartwychwstania do energii wzrostu zasianego ziarna i podkreśla, że obecne ciało ludzkie różni się od ciała zmartwychwstałego, ale musi zachować swoją tożsamość, bo „to właśnie dzięki ciału każdy człowiek może przeżywać w świecie swoje osobiste istnienie. Ciało określa całego człowieka i jego historyczne trwanie. W nim urzeczywistnia się nasza wolność i nawiązują relacje z innymi ludźmi. Będąc ciałem, człowiek trudzi się, działa, tworzy, doznaje radości, kocha i cierpi, czyni dobro lub zło. Całe ludzkie dzieje spełniają się w ciele. Tak pojęte ciało nie utożsamia się bynajmniej z biologiczną materialnością człowieka. Jest rzeczywistością o wiele bogatszą. W pewnym stopniu nasze ciało jest już teraz ciałem duchowym, obdarzonym zdolnością myślenia, mówienia i przekraczania samego siebie w swoich pragnieniach i dążeniach" ${ }^{26}$. Komentując paradoksalne wyrażenie Bernarda Sesboüé:

\footnotetext{
$22 \quad$ Por. S. Kunka, Teologiczna wizja..., dz. cyt., s. 41n.

$23 \quad$ Por. tamże, s. 49.

$24 \quad$ Por. tamże, s. 53.

25 Por. tamże, s. 65.

$26 \quad$ W. Hryniewicz, Oczekuję życia $w$ przyszłym świecie. Wydarzenia ostateczne $w$ dialogu chrześcijan, Poznań 2013, s. 172n.
} 
„Przez moc Ducha Bożego ciało stanie się więc duchem, podczas gdy duch stanie się niezniszczalnym ciałem", Hryniewicz napisał:

tego rodzaju paradoks nie mieści się w granicach naszej ludzkiej logiki i wyobraźni. Samo pojęcie ciała duchowego ${ }^{27}$ - sōma pneumatikón - nie jest jednak sprzecznością ani ontologicznym absurdem. Karl Rahner wyjaśniał przed laty, że materia jest stanem „ducha zamrożonego”. Pod wpływem platonizmu przywykliśmy do przeciwstawiania sobie niematerialnego świata ducha i cielesności, a to nie jest zgodne z zasadami antropologii chrześcijańskiej. Sam człowiek jest przecież duchem wcielonym, który przenika rzeczywistość ciała. Ucieleśnienie ducha jest jego manifestacją i żywym objawieniem w rzeczywistości świata. Ciało zmartwychwstałe staje się bezpośrednim objawieniem ducha, niejako jego zwierciadłem, jego transparentnym obrazem i jego chwałą ${ }^{28}$.

Dlatego też odosobniona i zadziwiająca była opinia niektórych Ojców Kościoła (m.in. św. Grzegorza z Nyssy), że w zmartwychwstaniu zaniknie zróżnicowanie płci oraz związane z nią cechy cielesne i duchowe. Sprzeciwia się temu realizm Wcielenia, potwierdzający pierwotny charakter płci męskiej Chrystusa i żeńskiej płci Maryi, Jego Matki - wskrzeszonej i wziętej wraz z ciałem do nieba. Zróżnicowanie płci jest przecież odzwierciedleniem pełni obrazu Bożego: „Stworzył więc Bóg człowieka na swój obraz, na obraz Boży go stworzył: stworzył mężczyznę i niewiastę" ( $\mathrm{Rdz} 1,27)^{29}$. Nie można jednak nie dostrzec

27 „Duchowy charakter ciała po zmartwychwstaniu oznacza przede wszystkim moc i władzę ducha nad ożywionym ciałem [...] całkowitą przenikalność i posłuszeństwo ciała względem ducha. To duch przezwycięża opór ciała i wyzwala je od ziemskich ograniczeń. Taką wolność osiągnąć można dopiero w ostatecznym spełnieniu. Trzeba jednak najpierw przejść (Pascha!), mocą Chrystusa, przez śmierć i zmartwychwstanie. To On «przemieni nasze poniżone ciało na podobne do swego chwalebnego ciała, mocą, którą może podporządkować sobie wszystko» (Flp 3, 21). Życie chwalebnego ciała, wraz z jego zmysłami, nie zostaje bynajmniej zniesione, ale staje się ze wszech miar czyste, przejrzyste, wolne i pełne radości. Jest to «wyzwolenie z niewoli skażenia», któremu według słów Apostoła poddane zostało całe stworzenie. Ono «wzdycha i rodzi w bólach» oczekując objawienia się «wolności chwały dzieci Boga» (Rz 8, 21-22). Nie doświadczamy tej pełni wolności w czasie życia ziemskiego. Według określenia Bułgakowa «ciało duchowe» [...] «jest nie uczynioną rękami ludzkimi ikoną ducha» [...]. To dzieło dobroci i łaskawości Boga, jakkolwiek kształtowane w całym ziemskim życiu człowieka. To, co w pewnej mierze każdy tworzy swoim życiem i współdziałaniem, zostaje uwieńczone chwałą zmartwychwstania i nieśmiertelnością. Paweł porównał ten ludzki współudział do budowania życia «ze złota, srebra, szlachetnych kamieni, drewna, trawy, słomy» - z takim rezultatem, że «dzieło każdego stanie się jawne» (1 Kor 3, 12-13), wypróbowane przez oczyszczający ogień przemiany" (tamże, s. 177n).

Tamże, s. 173.

Por. tamże, s. 175. 
w refleksji nad pierwszymi wiekami chrześcijaństwa, że duszy przyznawano pierwszeństwo jako specjalnemu wymiarowi, w którym daje się poznać obraz człowieka stworzonego na obraz Boga. Spowodowane to było stopniowym zapominaniem o stwórczym pośrednictwie Jezusa Chrystusa. Stąd brakowało także w literaturze teologicznej właściwego zrozumienia antropologicznej wartości ciała. Dlatego w tradycji aleksandryjskiej Słowo było uprzywilejowane jako Archetyp człowieka, podczas gdy od św. Augustyna to dusza miała być obrazem Trójcy Świętej, a w teologii patrystycznej brakowało przemyśleń wyjaśniających właściwie sens jedności duszy i ciała w człowieku ${ }^{30}$.

W kontekście bliższego opisu cielesności zmartwychwstałego Jezusa - która stała się dla św. Pawła podstawą cytowanej już wypowiedzi o zmartwychwstaniu umarłych (1 Kor 15, 42-44) - istotną refleksję antropologiczną na temat ciała ludzkiego przedstawił Gerhard Ludwig Müller: cielesność człowieka nie ogranicza się do samych wymiernych, fizjologicznych i biologicznych aspektów ciała. Jako medium osoby ciało stanowi podstawę możliwości rozwoju i działania oraz animacji osobowej tożsamości tak przez kontakty międzyosobowe, jak również w transcendentalnym odniesieniu do Boga. Dusza duchowa to zarówno forma substantialis ciała, jak i zasada jedności cielesno-duchowej. Historia życia człowieka to stopniowe ucieleśnianie osobowego ducha i wzrastające uduchowianie ciała. Śmierć nie oznacza tylko zerwania nici łączącej dwie heterogeniczne substancje, lecz jest niszczącą ingerencją w samo centrum osobowości człowieka. Dotyczy ona zarówno jego duchowości i wolności, jak też płaszczyzny jego stawania się za pośrednictwem ciała w relacjach międzyosobowych. Obecni przy zmarłym ludzie nie mają przed sobą znanego człowieka, tylko jego zwłoki, które są dowodem, że zmarły nie jest już wolnym podmiotem i nie można spotkać się z nim na płaszczyźnie osobowej. Komunikacja przez ciało została zerwana. Zwłoki, jako zakrzepła historia człowieka, dają jeszcze tylko możliwość kontaktu z przeszłością zmarłego, a pozostali przy życiu mogą się odnieść do niego jedynie pośrednio przez sięgnięcie do własnej pamięci ${ }^{31}$.

$30 \quad$ Por. A. Scola, Osoba ludzka..., dz. cyt., s. 173n.

31 Chrystologia - nauka o Jezusie Chrystusie, Kraków 1998, s. 240n. 


\section{Komunijne znaczenie duszy człowieka}

Człowieka można widzieć po platońsku jako samodzielną istotę osobową, opartą na duchowej rzeczywistości zwanej „duszą" 32 , jako duszę lub osobę „w ciele" rozumianym negatywnie ${ }^{33}$. Antropologia chrześcijańska rozwinęła się na podstawie tekstów biblijnych. Termin psyche odnoszony był do jednego z elementów natury jako substancja duchowa lub jej duchowe wyposażenie ${ }^{34}$. Biblijny model wskazuje

32 Na temat terminologii, rozwoju poglądów i teologii duszy zob. C. S. Bartnik, Dogmatyka..., dz. cyt., s. 380-389. P. Liszka zwraca uwagę na konieczność precyzyjnego rozróżniania w teologii terminów biblijnych i odpowiadających im przekładów: „Grecki czytelnik Septuaguinty, napotykając termin psyche, bez głębszego zastanawiania się utożsamiał nefesz i ruach. Podobnie w języku polskim mówienie o duszy jest mało precyzyjne i w praktyce następuje utożsamienie treści obu terminów hebrajskich, jak również odpowiadających im terminów greckich. W myśleniu hebrajskim ruach jest działaniem Boga, a nawet jest utożsamiane z Bogiem, natomiast nefesz jest skutkiem tego działania, jako element natury ludzkiej. W myśli greckiej psyche to przede wszystkim dusza świata, rozumiana w sposób panteistyczny,jako element boski i ludzki zarazem. Rozumienie rzeczywistości określanej terminem «dusza» w sposób hebrajski może prowadzić do wniosku o śmiertelności duszy, z kolei ujmowanie jej w sposób pozabiblijny ogranicza jej zakres semantyczny, nadany przez Pismo Święte. Termin grecki psyche, który pojawił się w judaizmie międzytestamentalnym zamiast hebrajskiego nefesz oznacza podmiot życia wiecznego i nieśmiertelności. Termin nefesz wskazuje na integralność człowieka, psyche natomiast wskazuje na coś, co przetrwa po śmierci człowieka. Taki aspekt jest ważny w refleksji nad wydarzeniem paschy Jezusa, nad sytuacją Jezusa po śmierci i zrealizowaną możliwością zmartwychwstania" (Interpretacja terminu psyche $w$ Piśmie Świętym i w teologii, „Teologia w Polsce” 7 (2013) nr 2, 51). W oparciu o swoje analizy Liszka dokonuje dość zaskakującego stwierdzenia: „Okazuje się, że Nowy Testament jest bardziej dualistyczny niż hellenizm. Dualizm nie pojawił się pod wpływem hellenizmu, lecz odwrotnie, to Nowy Testament jest samodzielnym źródłem dualizmu, i to chrześcijaństwo wniosło dualistyczną antropologię w obszar myśli greckiej. Absurdalny jest więc postulat odejścia od dualizmu hellenistycznego i powrotu do myślenia biblijnego" (tamże, 53).

Por. L. Lies, Sakramententheologie. Eine personale Sicht, Graz - Wien - Köln 1990, s. 55. K. Góźdź ukazuje Rahnerowskie ujmowanie człowieka jako „duchowej osoby” i „osobowego ducha” (por. Droga ku człowiekowi, Lublin 2011, s. 25-30).

P. Liszka, Interpretacja..., dz. cyt., s. 55: „trzeba się zastanowić nad tym, jaka jest różnica znaczeniowa między psyche i pneuma, a także czy jest różnica między terminami psyche i dusza oraz między pneuma i duch? Odpowiednio: Jaka jest różnica w języku polskim pomiędzy terminami «dusza» i «duch»? Czy dokładnie taka, jak w języku greckim między psyche i pneuma, czy trochę inna? Bardzo często pole semantyczne danego słowa polskiego jest utożsamiane z zakresem znaczeniowym słowa greckiego. Ponadto pojawia się pytanie, czy ciało, dusza i duch to już wszystkie aspekty człowieka, czy wystarczają do opisania obrazu całego człowieka. Skoro wiadomo, że nie, więc dlaczego inne 
raczej na człowieka jako na „ciało w osobie”. Tak rozumiany człowiek posiada nie tylko swoją indywidualność, lecz także własny sposób transcendencji. Cieszy się wolnością i może trwać we wspólnocie z innymi ludźmi nie tracąc przy tym swojej tożsamości. W biblijnym opisie stworzenia nie chodzi jednak przede wszystkim o osobowość w cielesności, lecz o spotkanie człowieka z Bogiem, gdzie pierwotną i ostateczną podstawą pośredniczenia jest nie ciało, lecz przestrzeń wolności osoby ${ }^{35}$. Spotkanie Boga z człowiekiem dokonuje się między osobami urzeczywistniającymi się w różny sposób. Dzięki Wcieleniu (unii hipostatycznej) Bóg przyjął człowieka jako „ciało w osobie” do siebie i dał mu miejsce w centrum swojej osoby. W teologicznym obrazie świata Bóg, który jest centrum całej rzeczywistości, nie tyle zstępuje ku człowiekowi, co przyjmuje go do siebie ${ }^{36}$. Jeśli tak jest, to spotkanie osobowe z Bogiem zakłada uprzednio osobowość człowieka ${ }^{37}$.

W teologii patrystycznej brakowało przemyśleń wyjaśniających właściwie sens jedności duszy i ciała w człowieku. Kiedy św. Tomasz z Akwinu zaangażował się w ukazanie racji, z powodu których dusza jest formą ciała, podjął tezę, że człowiek nie jest utworzony przez zwykłe zbliżenie się do siebie dwóch kompletnych rzeczywistości istniejących uprzednio i połączonych tylko przypadłościowo. Pojmował je natomiast jako dwie zasady, mocą których pojawił się człowiek w swej pierwotnej jedności, bez której nie można mówić o człowieku, że jest imago Dei. Przyjęcie dwóch elementów konstytucyjnych narażało Tomasza na ryzyko kwestionowania nieśmiertelności duszy (gdyby poszedł do końca za antropologią Arystotelesa). Poszedł jednak za Pseudo-Dionizym i utrzymywał, że dusza intelektualna jest substancjalną formą człowieka, gdyż „rekapituluje” w sobie wszystkie formy niezbędne do zaktualizowania człowieka. Sobór w Vienne dokonał

aspekty są pomijane, dlaczego nie ma ujęć integralnych, ujmujących wszystkie aspekty i wszelkie powiązania między nimi, relacje między nimi a całością? Ostatecznie potrzebne jest ujęcie całościowe, integralne. Celem powyższego określenia nie było podanie odpowiedzi na wszystkie postawione tu pytania, lecz jedynie poinformowanie, że termin pneuma akcentuje powiązanie natury ludzkiej z boskością, natomiast termin psyche wskazuje na to, co jest w naturze ludzkiej jak najbardziej własne".

35 Por. L. Lies, Sakramententheologie..., dz. cyt., s. 56n.

36 Por. D. Staniloae, Obraz, podobieństwo i przebóstwienie w osobie ludzkiej, [w:] L. Balter, K. Czulak, P. Góralczyk (red.), Kosmos i człowiek, Poznań - Warszawa 1989, s. 240-257.

37 Por.L.Lies, Sakramententheologie..., dz.cyt., s. 61n; M. Jagodziński, Sakramenty w stużbie communio..., dz. cyt., s. 177n; tenże, Człowiek $w$ perspektywie komunii, s. $23 \mathrm{n}$. 
chrystologicznego pogłębienia tej tezy nauczając, że „Jednorodzony Syn Boży [...] przyjął części naszej natury tworzące jedność [...] to znaczy ludzkie ciało podległe cierpieniu oraz duszę intelektualną czyli rozumną, prawdziwie i pod względem istoty kształtującą ciało" 38 .

Ograniczenie nauki o duszy dokonało się w dobie nowożytnej, która chciała patrzeć na ciało i duszę jako na rzeczywistości z góry sobie przeciwne i oddzielne. Teologia szkolna broniła złożoności człowieka przeciwko dualizmowi albo monizmowi (spirytualistycznemu lub materialistycznemu). W specyficznej konstytucji człowieka jako jedności duszy i ciała nie można jednak pojmować duszy jako „czegoś innego” od ciała, lecz jako współzasadę człowieka pełniącą rolę formy ciała - ona jest „duchem ciała”. Jeżeli nie można u człowieka oddzielić momentu stworzenia od wybrania do komunii z Bogiem, to duszy nie można traktować jako istniejącej uprzednio „podpory ontologicznej”, która później dopiero pozwalałaby człowiekowi ustalić swoją relację do Boga. Dusza jest nieśmiertelna właśnie dlatego, że ma udział w naturze samego Boga, który stworzył człowieka i powołał go do komunii ze sobą w sposób nieodwołalny. Jej nieśmiertelność zaś można pojąć w pełni i właściwie tylko w perspektywie zmartwychwstania umarłych ${ }^{39}$.

\section{Chrystologiczny kontekst komunijnej integralności człowieka}

Fenomen komunii jest zasadniczo rzeczywistością międzyosobową. Tak jest w przypadku fundamentalnej Komunii wewnątrztrynitarnej, komunii międzyludzkiej i komunii człowieka z Bogiem ${ }^{40}$. Czy integralność człowieka polegająca na zjednoczeniu w nim duszy i ciała mogłaby być traktowana jako integralność komunijna? Pewną możliwość takiego myślenia zdaje się otwierać prawda o unii hipostatycznej w Jezusie Chrystusie, który jest nazywany „komunią w Osobie”.

Komunia w Jezusie Chrystusie dotyczy przede wszystkim zjednoczenia natur w Jego osobie ${ }^{41}$. On jest osobową komunią Bóstwa i człowie-

38 Dekrety [1. Btędy Piotra Jana Olivi], 1, 1a, [w:] A. Baron, H. Pietras (red.), Dokumenty Soborów Powszechnych, t. II, Kraków 2003, s. 533. Por. A. Scola, Osoba ludzka..., dz. cyt., s. 174-177.

Por. A Scola, Osoba ludzka..., dz. cyt., s. 177-181.

Zob. np. M. Jagodziński, Teologiczne znaczenie pojęcia koinonia, „Zeszyty Formacji Katechetów" 11 (2011) nr 3 (43), s. 30-35.

Ksiądz Jerzy Szymik, pisząc o komunijnej strukturze rzeczywistości, posługuje się terminem „teandryczność”: „teandryczność - w jej możliwie najgłębszym chrystologicznie znaczeniu, interpretowanym soteriologicznie - jest tu źródłem i celem komunii, jej wewnętrzną treścią, a zarazem źródłem i celem 
czeństwa ${ }^{42}$, ,jest teandrycznością samą, jej przyczyną, źródłem i celem; którego zarówno Osoba, jak Dzieło są komunią Bosko-ludzką, jedyną w swoim rodzaju, komunią, by tak rzec, «w stanie czystym»" 43 . On otwiera drogę do komunii Boga i człowieka, ponieważ sam jako Słowo Wcielone jest tą komunią. W nim zrealizowała się „alchemia” przemieniająca byt ludzki w byt Boży, a droga do wzajemnej komunii ludzi prowadzi przez komunię z Bogiem. Dogmat chrystologiczny Soboru Chalcedońskiego z 451 roku ujmuje Jezusa Chrystusa jako istotową komunię natury ludzkiej i Boskiej „bez zmieszania, bez zmiany, bez podzielenia i bez rozłączania" ${ }^{4}$. W ramach ówczesnych problemów i filozofii ukuto określenie tzw. unii hipostatycznej. Osoba Boskiego Logosu przyjęła ludzką naturę, w wyniku czego dwie natury - Boska i ludzka - zostały zjednoczone i zachowały swoje istotne wyróżniki ${ }^{45}$. Komunia natur w Chrystusie wyrażana jest pojęciem perichoresis, co oznaczało pierwotnie wzajemny taniec tancerzy wokół siebie, w myśleniu stoickim i neoplatońskim - zjednoczenie i wzajemne przenikanie się duszy i ciała w człowieku, a w teologii posłużyło najpierw do wyrażenia wzajemnego przenikania się Bóstwa i człowieczeństwa w Jezusie Chrystusie przy jednoczesnym zachowaniu właściwości natur - aby komunię natur w Nim rozumieć jako komunikację osobową ${ }^{46}$.

Czesław Stanisław Bartnik stwierdził, że dualistyczna myśl hellenistyczna znajduje ciągle kontynuację w poglądach redukujących człowieczeństwo Jezusa. Biblia łączy wprawdzie obie Jego natury, ale sam problem jest niezwykle skomplikowany. Czy pełne człowieczeństwo Jezusa obejmuje także „osobę ludzką"? Kwestia ta nie została rozwiązana w teologii. Sobór Chalcedoński przyjął w Jezusie Chrystusie jedną Osobę Słowa i „dwie” natury - Boską i ludzką, przy czym „naturę ludzką” uznał za „człowieka doskonałego”, „prawdziwego”,

wszechrzeczywistości, której człowiek jest reprezentantem i w której (i dla której) jest obrazem i podobieństwem Boga ( $\mathrm{ddz} 1,26-27)$ " (Theologia benedicta, t. II, Katowice 2012, s. 151n).

Por. J. Ratzinger, Pielgrzymujaca wspólnota wiary. Kościót jako komunia, Kraków 2003, s. 70-74; A. A. Napiórkowski, Misterium communionis. Eklezjalny paradygmat dziejów zbawienia, Kraków 2006, s. 112-122.

J. Szymik, Theologia benedicta..., dz. cyt., s. 176.

Definicja wiary 11, [w:] A. Baron, H. Pietras (red.), Dokumenty Soborów Powszechnych. Tekst grecki, taciński, polski, t. I (325-787), Kraków 2001, s. 223. Por. G. Greshake, Trójjedyny Bóg. Teologia trynitarna, Wrocław 2009, 319. 
„pełnego” i „wspólistotnego nam”. Dlatego ogół teologów uczył, że osobą w Jezusie Chrystusie była tylko Osoba Słowa ${ }^{47}$. Zmieniło się jednak rozumienie „osoby”. Dawniej przez „człowieka” rozumiano „ciało i duszę”, a „osobę” jako pewną rolę w ekonomii Bożej (pod wpływem stoicyzmu) albo samoistny byt (w arystotelizmie), ale bez odniesienia do intelektu, woli i działania - czyli bez odniesienia do podmiotowości, jaźni. Twierdzenie, że Jezus jest prawdziwym i pełnym człowiekiem, ale nie ma osoby ludzkiej (czyli nie jest osobą ludzką!) stało się dzisiaj niedorzeczne (i oznacza jakiś powrót do doketyzmu lub apolinaryzmu). Dlatego też Karl Barth i Karl Rahner sugerowali odejście od terminu „osoba” w przypadku Jezusa i pewne korekty semantyczne ${ }^{48}$. Bartnik uważa, że w bardzo trudnej sytuacji znaleźli się tomiści (sam św. Tomasz odróżniał w człowieku „duszę” i „osobę”), którzy w większości utrzymują, że „osoba” i „dusza” są ontologicznie tożsame. To oznaczałoby dla nich, że odrzucenie apolinaryzmu jest czystym nestorianizmem, ponieważ jeśli Jezus ma stworzoną „duszę ludzką", to i stworzoną „osobę ludzką" - a więc w Jezusie jest osoba ludzka i osoba Boska. Tomistyczna nauka o osobie domaga się jednak realnego rozróżnienia w każdym człowieku „duszy” i „ciała” - a więc i rzeczywistej osoby ludzkiej w Jezusie. Jak to rozwiązać, skoro w Jezusie Chrystusie jest tylko jedna Osoba? ${ }^{49}$. Bartnik zaproponował hipotezę „spełnienia osobowego":

Jezus jako człowiek jest „pełną osobą ludzką”, ale w wymiarze osobowym nie jest różny od „Osoby Słowa”, gdyż stał się osobą przez Osobę Słowa, w Niej i dla Niej (por. Kol 1,16). Jezus był sam z siebie relacją ku Osobie Słowa, możnością bycia Kimś Jednym z Synem Bożym, Kimś „najbliższym” do zrealizowania się w Osobie Bożej. Osoba Słowa „wosobiła” (enhypostasis) Jezusa w siebie jako Osobę przez akt personogenetyczny, nie przez unię czy asumpcję prostą $^{50}$. Nie jest to contra naturam humanam, gdyż osoba stworzona jest sama z siebie absolutną relacją ku Osobie Niestworzonej. Jezus spełnia się osobowo w Osobie Słowa w sposób absolutnie szczególny. Mówiąc „od strony ludzkiej”, Jezus - ontyczny, historyczny, psychiczny, podmiotowy jako „Ja Jezusowe” realizował się w Osobie Syna Bożego, która „Jest” i ciągle „się staje", ciągle się realizuje i do tego procesu Osoba Boża włączyła Jezusa, jednocześnie Go stwarzając. Przy tym osoba ludzka zostaje „wrodzona”

47 Por. C. S. Bartnik, Dogmatyka..., dz. cyt., 586-588.

$48 \quad$ Por. tamże, s. 588.

49 Por. tamże, s. 588n. M. Jagodziński, Węzłowe zagadnienia..., dz. cyt., s. 179n.

$50 \quad$ Bartnik uważa, że teoria enhipostazy (insubsystencji, inegzystencji) rozwiązuje ten problem w znaczeniu zbyt aleksandryjskim, w duchu absolutnej hegemonii Logosu i z uszczerbkiem dla człowieczeństwa Jezusa (por. tamże, s. 791). 
w Osobę Słowa przez Ducha Świętego za pośrednictwem Matki, Maryi. [...] A zatem osoba Jezusa w relacji ku sobie samej jest integralną osobą, stwarzaną i powoływaną przez Osobę Ducha Świętego, by w relacji do Osoby Syna identyfikować się z Osobą Niestworzoną. W tym przypadku Osoba Syna Bożego spełnia prozopoidalną relację Jezusa do Boga przez swoją Osobę Bożą i na miarę tej Osoby. Jest to Absolutne Misterium¹ ${ }^{51}$

Po tej samej linii poszedł Tadeusz Dionizy Łukaszuk. Osoba Boska Jezusa jest w sobie bezwzględnie prosta, ale kiedy widzi się ją w akcie podtrzymywania dwóch niezmieszanych natur - jest złożona. Dlatego przyjęło się mówienie, że Chrystus utożsamia się ze swoją Boską naturą, a naturę ludzką posiada na własność. Teologia o posmaku konserwatywnym wolała nie głosić, że jest On po prostu także naturą ludzką - natomiast dzisiejsza teologia dopuszcza dyskusję na ten temat $^{52}$. W związku z tym Bartnik stwierdza jasno: „z nauki Soboru Chalcedońskiego wynika, że Jezus jest pełnym człowiekiem, łącznie $\mathrm{z}$ «osobą» w dzisiejszym znaczeniu tego słowa; spełnia ją w niepojęty sposób Osoba Słowa Bożego samą Sobą" ${ }^{53}$. Łukaszuk relacjonuje także teorię Jeana Galota usiłującą opisać osobę przez kategorię relacji ${ }^{54}$. Bytowość relacyjna nie dodaje niczego naturze, jest „relacją samoistną" lub „hipostatyczną” - to znaczy tworzącą hipostazę. Osoba włada naturą nawet wtedy, gdy się z nią nie utożsamia, jest podmiotem aktywności i podejmuje odpowiedzialność za jej działania. Zastosowanie takiego pojęcia osoby w chrystologii jest łatwe i korzystne. Skoro odwieczne Słowo jest w swoim bycie relacją samoistną, to włączenie w niego bytu o podobnej strukturze dokonuje się prawie naturalnie. Człowieczeństwo Chrystusa nie traci nic ze swych naturalnych właściwości, a tylko czysto ludzka relacja zostaje zastąpiona osobową relacją Słowa ${ }^{55}$. Dlatego ludzka natura Jezusa cieszy się pełnym i przebogatym wyposażeniem osobowym - bez jakiegokolwiek niedostatku ${ }^{56}$.

Tamże, s. 589. Por. tamże, s. 590, 790-794.

Por. T.D.Łukaszuk, Tyjesteś Chrystus, Syn Bogażywego. Dogmatchrystologiczny w ujęciu integralnym, Kraków 2000, s. 387-390.

C. S. Bartnik, Dogmatyka..., dz. cyt., s. 590. Por. T. D. Łukaszuk, Ty jesteś..., dz. cyt., s. 390-395; M. Jagodziński, Węzłowe zagadnienia..., dz. cyt., s. 182n.

54 Por. La définition de la personne, relation et sujet, „Gregorianum” 75 (1994), s. 281-299.

Por. T. D. Łukaszuk, Ty jesteś..., dz. cyt., s. 403-408.

Por. tamże, s. 395-399; M. Jagodziński, Węzłowezagadnienia..., dz. cyt., s. 181-184. 
Komunią Boskości i człowieczeństwa w Jezusie Chrystusie zajął się także Gerald O'Collins ${ }^{57}$. Jak było możliwe połączenie w Chrystusie Boskiej nieskończoności i ludzkiej skończoności? „W odniesieniu do swego bóstwa, Chrystus jest wszechwiedzący, w odniesieniu do człowieczeństwa jest natomiast ograniczony w swojej wiedzy. Przypisuje Mu się wzajemnie wykluczające się cechy, ale nie w tym samym układzie odniesienia" ${ }^{58}$. Arcybiskup Edward Ozorowski rozwiązuje ten problem przy pomocy idei przebóstwienia człowieka:

Osoba i natura zawierają w sobie odpowiedź na pytania: Kim jest Jezus Chrystus? [...] Bardzo ważnym przy tym jest czasownik egeneto. Słowo stało się ciałem, nie przestając być Słowem. Syn Boży stał się człowiekiem, nie przestając być Synem Bożym. Osoba Boska stała się osobą ludzką, nie przestając być Osobą Boską. Stać się w tym znaczeniu nie oznacza przestać być sobą ani ontycznie, ani etycznie lub psychicznie. Przy poczęciu człowieka pierwsza jest osoba, a nie natura. Poczyna się osoba w ludzkiej naturze, a nie natura, która staje się osobą. Osoba transcenduje naturę. Podobnie jest w Jezusie Chrystusie. Maryja poczęła Syna Bożego, który w Jej łonie stał się Synem Człowieczym ${ }^{59}$.

Komunia jest rzeczywistością komunikacji międzyosobowej, toteż tradycyjne mówienie o osobowym zjednoczeniu natur w Chrystusie sprawia problemy wynikające ze współczesnego rozumienia osoby. Współczesne próby rozwiązań tego problemu usiłują bardziej precyzyjnie formułować wypowiedzi na temat unii hipostatycznej, co być może pozwala także na bardziej personalistyczne postrzeganie istoty „hipostatycznego” związku ciała i duszy w człowieku i łatwiejsze dostrzeganie analogicznego wymiaru komunijności tego związku.

Słowa kluczowe: człowiek, ciało, dusza, integralność, komunikacja, komunia, unia hipostatyczna, zmartwychwstanie.

57 Zob. G. O'Collins, Chrystologia. Jezus Chrystus w ujęciu biblijnym, historycznym i systematycznym, Kraków 2008, s. 214-222.

Tamże, s. 223n. G. O’Collins wskazuje na stojące niekiedy u podstaw współczesnych poglądów chrystologicznych pomieszanie pojęć i zapominanie o analogicznościjęzyka teologicznego, a także proponuje własne rozwiązanie-chrystologię obecności.Por. tamże, s.233-237. Dzisiejsze chrystologie „chalcedońskie” muszą borykać się także z dalszymi pytaniami: Jaka jest ludzka natura Chrystusa, jeśli nie jest On osobą ludzką? Jak jedna osoba może mieć dwie świadomości: Boską i ludzką? Co wtedy z odpowiedzialnością osoby? Jakich sił sprawczych (jakiej natury) używał Chrystus w swoim ziemskim życiu. Por. M. Jagodziński, Węzłowe zagadnienia..., dz. cyt., s. 184-187.

59 Humanitas unii hipostatycznej, [w:] A. Proniewski, A. Dębski (red.), Człowieczeństwo Boga, Białystok 2013, 19. 